\title{
A DUAL MODEL TO PREDICT THE Peronospora sparsa SPORULATION IN ROSE BASED ON THE PLANT MICROCLIMATE
}

Fecha de recepción: 24 de Febrero de 2014 • Fecha de aceptación: 06 de Junio de 2014

\section{UN MODELO DUAL PARA PREDECIR LA ESPORULACIÓN DE Peronospora sparsa EN ROSA BASADO EN EL MICROCLIMA DE LA PLANTA.}

Juan José Filgueira' ${ }^{1,2}$, Katherin Velasquez

\section{ABSTRACT}

Roses are the most important product exportation of flower industries in Colombia, and the downy mildew produced by Peronospora sparsa Berkeley is the most limiting disease. The attack prediction is an important tool to prevent and combat this disease, decreasing the flower production cost. P. sparsa depends of microclimate conditions for its biological development. In this work, a dual model to predict sporulation is presented based on the known temperature and relative humidity near the plant (microclimate) during the night before to the prediction, allowing a reliability level above $95 \%$ on determining the parasite sporulation and with that information take a decision about the fungicide application in the crop.

Keywords: Rosa sp., Modeling, Peronosporal.

\section{RESUMEN}

Las rosas son el producto más importante de exportación de la industria de flores en Colombia, y el mildeo producido por Peronospora sparsa Berkeley es la enfermedad más limitante. La predicción de ataque es una herramienta importante para prevenir y combatir la enfermedad, disminuyendo el costo de producción de la flor. P. sparsa depende de las condiciones microclimáticas para su desarrollo biológico. En este trabajo, se presenta un modelo dual para predecir la esporulación, basado en el conocimiento de la temperatura y la humedad relativa cerca de la planta (microclima) durante la noche anterior a la predicción, y permitiendo un nivel de fiabilidad por encima del 95\% en la determinación de la esporulación del parásito y con esa información tomar una decisión sobre la aplicación de los fungicidas en el cultivo.

Palabras Clave: Rosa sp., Modelamiento, Peronospora.

1. Molecular plant pathology laboratory, Military University "Nueva Granada", Cajica, Colombia.

2. Corresponding Author: juan.filgueira@unimilitar.edu.co 


\section{INTRODUCTION}

The rose downy mildew produced by Peronospora sparsa, is one of the most expensive disease for the flower cultivator in Colombia (Castillo et al., 2010), due to excessive use of fungicides, to prevent the parasite attack (Ayala et al., 2008). Other factor of cost in the rose production is the stem loss by the spots presence, produced by the downy mildew pathogen activity, in the season of more incidences (Gómez and Filgueira 2012).

Peronospora sparsa Berkeley is within the Phylum Oomycota, Class Oomycetes, Order Peronosporales, Family Peronosporaceae (Prescott, 1999). Is a biotrophic obligate parasite; since 1994 it was locate out of the fungi kingdom. Is consider like a pseudofungi, because it cellular wall is composed by cellulose (Margullis, 1998). In Colombia, this is the parasite responsible by the disease of rose downy mildew (Arbeláez, 1999; Gómez and Arbeláez, 2005; Soto and Filgueira, 2009).

Since a long time is recognize that the ambient conditions determinate the attack in the genera (Wheeler, 1981). Low temperature and high relative humidity are conditions that are established like ideal for the parasite development, in species that are important in countries localized above the subtropical zone, like the case of $P$. destructor, $P$. vitícola, P. tabacina, etc. (Virnnot-Bourgin, 1981; Hildebrand and Sutton, 1984; 1985), and P. sparsa in Colombia rose case (Gómez, 2004). According to Horst (1983), the disease is favored by humidity above $90 \%$, the sporangia germination is better near the $18^{\circ} \mathrm{C}$ and it does not germinate below $4^{\circ} \mathrm{C}$ neither above of $27^{\circ} \mathrm{C}$. That why, a used control measured into the Colombian greenhouses, has been maintain a high temperature with a good ventilation, to reduce the humidity (De Vis, 1999, Monroy and Filgueira, 2009).

Models that predict the Peronospora attacks were early develop by Hildebrand and Sutton (1984, 1985), to predict the $P$. destructor behavior in onion crops; concluding that the infection process could be summarized in four stages: germination, penetration, tissue colonization and sporulation. In the case of vid mildew, Hoppmann and contributors (1997), develop an epidemiologic model based on the duration of the free water over the leaf, to predict parasite attacks. More recently Soo and collaborators (2014), developed a model to predict the attack of $P$. sparsa in boysenberry, based on humidity and temperature variables. For the case of the rose downy mildew in United State, Aegerter and collaborators (2003), developed a model of $P$. sparsa prediction attacks in propagation seedling, based on ambient conditions, that model has been evaluated in Colombia with a low or limited success.

In the present work, a dual model for the prediction of $P$. sparsa sporulation is proposed, under controlled condition and below not controlled condition, as we can get in the classical greenhouses in the Bogota Savanna in Colombia. Using information of climate variables like the humidity and the ambient temperature near the plant (microclimate) in the crop, to predict the sporulation intensity and this prediction will help to the rose grower, to take a decision about the fungicide application in controlled form.

\section{EXPERIMENTAL}

\section{Assays under controlled condition (CCA)}

The present work was developed in the Plant Biotechnology Laboratory in the Military University "Nueva Granada", in the Cajica municipality (Cundinamarca), between the years 2008 and 2013. We build a laboratory of controlled climate conditioned, whose characteristics were describe by Soto and Filgueira (2009) and Gomez and Filgueira (2012), where the light intensity was graduated of $40 \mathrm{~W}$ to 240W (lumen/m2, Ix), generating since 0.7 up 1000lx. 
In that laboratory was possible to establish different photoperiod values, which simulated different seasonal conditions. The temperature was worked in a fringe since $4^{\circ} \mathrm{C}$ to $40^{\circ} \mathrm{C}$, as it is describe by Monroy and Filgueira (2009). The Relative Humidity (RH) into the installation was worked each $10 \%$ in a fringe between 30 and $100 \%$. The measures into the laboratory were carried out with a Data Logger WatchDog, model 450, two drum hygrothermographs Akton $®$ and two digital hygrothermographs, to calibrate the drum hygrothermographs.

To obtain the inoculum, we used infected leaflet with downy mildew sporulation, obtained of commercial plants, like was previously describe by Gomez (2005). The assays in chamber to produce new spores were done using rose leaflet from variety Charlotte, susceptible to downy mildew. The infection, sporulation and measures of spore germination, were done as Soto and Filgueira (2009) previously described it.

\section{Assays under not controlled conditions (NCCA)}

We realized a tracing of $P$. sparsa attacks in a group of commercial varieties (39), susceptible and resistant, sowed in an open field in a farm of Chia group (MG Consultores), localized in the Chia municipality in Cundinamarca (Colombia). The monitoring was done by a year between March of the first year to February of the next year, recording daily the temperature and relative humidity $(\mathrm{RH})$ in continuous records, using drum hygrothermographs, which permitted records of seven days continuous. During six days in the week, we made the monitoring in the plants leaflet of each variety. We examined the symptom apparition (spots) and sporulation apparition the next morning to the climate condition recorded. The sporulation observation was performed by taking the imprint in sticky tape, such that de sporulation was retired without damage to the leaflet. For data analysis, we build a matrix that link the sporulation presence in a scale of 0 to $5(0=0 \%, 1=10 \%, 2=20 \%$, etc.), according to the methodology of Bambelli and collaborators (2012) and the microclimate data the night before, between the 12:00am and 5:00am.

\section{Data analysis}

The data analysis was realized in each case, studding the variation that was observed in each one of the events of $P$. sparsa parasitism in the commercial rose, like the symptom presence, and the sporulation values. The data were analyzed by blocks of results and in statistic packages SAS巴 y $R \circledast$ (see Soto and Filgueira, 2009, for the photoperiod and lighting intensity; Monroy and Filgueira, 2009, humidity studies; Gómez and Filgueira, 2012, parasite development biology; Zambrano and Filgueira, 2013, temperature studies). For the model, the construction software was one that could be executed in an operative system Windows 7 (Microsoft $@$ ), with the program Java Development Kit of Oracle ${ }^{\circledR}$. For the results presentation we used a graphic interface (JavaFX Scene Builder) by Oracle $\AA$. To integrate the two programs we used the application NetBeans IDE 7.4. (Free software). For the algorithms design (does not show here), we define a function CE (calculation of the sporulation), that produced the different probabilities. The model validation and calibration was doing using statistic estimator, with the Pearson correlation coefficient calculated between the simulated values and the measured values with the STATGRAPHICS® program.

\section{RESULTS AND DISCUSSION}

\section{The light intensity and photoperiod}

How was previously demonstrated in other cases (Hildebran y Sutton, 1984), the light intensity and the photoperiod are two important variables for $\mathrm{P}$. 


\section{The data analysis was realized in each case, studding the varia- tion that was observed in each one of the events of $P$. sparsa parasitism in the commercial rose, like the symptom presence, and the sporulation values.}

destructor sporulation prediction in onion, that is valid for countries with seasons. However, in the Colombia case, the variation in light intensity that are directly related with the photoperiod, are not significant, by the equatorial position of the country. In work realized by our group by Soto and Filgueira (2009), we evaluated photoperiods of $8 / 16,12 / 12$, $16 / 8$ and 24/0 hours, with light intensity of 120, 560, 790 and 1000 Ix (by each photoperiod). We demonstrated how for 12/12 hours photoperiod, produced the most high sporulation values, and the variation of $8 / 16$ and $16 / 8$, does not show significant reduction of sporulation. With photoperiod of $24 / 0$ hours, the sporulation was reduced significantly (Soto and Filgueira, 2009), these results showed that in any time of year in Colombia, P. sparsa have the capacity of sporulate; because, the variation of effective light, never is greater than one hour. The above, together to the light intensity of $5601 x$, presented the highest values of sporulation (Soto y Filgueira, 2009), and in turn, that is the normal condition in a flower greenhouse in the region. We infer of foregoing, that the photoperiod and the natural light intensity are not factors that affect the P. sparsa sporulation in Colombia greenhouses.

Changes in the light condition into the greenhouses with artificial light in the night, with values near to $560-7601 x$, for a photoperiod of $24 / 0$, could be a useful and effective control tool. Because the sporulation reduction is about of $95 \%$, in comparison with the produced by the photoperiod into the range 8/16 and 16/8 (Hildebrand and Sutton, 1984, Soto and Filgueira, 2009). Unfortunately, the relation cost and benefice, does not permit this practice like control method. For the sporulation model prediction, the photoperiod variable and light intensity, does not alter the result when we compared with the sporulation data in field (data not shown). The seasons or month on the year is relevant in a direct form with the variation of humidity and temperature.

\section{The humidity}

In order to determinate the effect in the variation of the relative humidity, over the $P$. sparsa sporulation in leaflets of Charlotte variety, under controlled condition (CCA), we worked with a constant temperature of $20^{\circ} \mathrm{C}$ and with variation, not greater than, two degrees Celsius. Other parameters were Light intensity of $1000 \mathrm{~lx}$ and photoperiod of $12 / 12$, with ranges of $\mathrm{RH}$ variation of 40 to $100 \%$, like was previously described by Monroy and Filgueira (2009). Like is demonstrated in other cases (De Vis, 1999 and Aegerter, 2003), in rose, the $\mathrm{RH}$ determines two phases of the parasitism process. During the phase one, must not exist free water, because it inhibit 
the P. sparsa sporangiophores formation. This process is produced during the three or four first hours depending of the temperature; the phase two begins three hour after of the beginning of sporangia formation and is extending to the fifth hour, in that phase is necessary the free water presence to permit the sporangia distribution and germination (Gómez and Filgueira 2012).

Our results in conditioned laboratory and CCA, showed clearly how the maxima sporulation is present near $90 \%$ of $\mathrm{RH}$ and decrease quickly to $\mathrm{RH}$ between 60 and $80 \%$, underneath it $\mathrm{RH}$ is not possible the sporulation (Monroy and Filgueira, 2009). For the purposes of sporulation model, in the $\mathrm{RH}$ case, is permitted an error range approximately in the data record of $+/-3 \%$, the same range of variation was applies in the case of the temperature. Similarly, the records of temperature and $\mathrm{RH}$ that were considered, to be used with the model are those that are acquired the night before between the 12am and $5 \mathrm{am}$.

In accord with the anterior information and for the CCA case, for $\mathrm{RH}$ minor or equal to $68 \%$, the sporulation probability in the case of the humidity (Ph) is zero. If the RH was between 69 and 78\%, the sporulation probability is of $25 \%$. If the $\mathrm{RH}$ registered was between 79 and $84 \%$, Ph take the value of $50 \%$. If the $\mathrm{RH}$ was between 85 and $90 \%$, Ph take the value of $75 \%$, but if the $\mathrm{RH}$ overcome $90 \%$, Ph take the value of $100 \%$ (see Table 1).

For the case of the data of sporulation in field conditions or assays under not controlled conditions (NCCA), the data were taken between the month of March of the first year and February of the next year. The data of temperature and $\mathrm{RH}$ were tabulated the 340 days of experiment duration, between the $12 \mathrm{am}$ and $5 \mathrm{am}$ (data not showed here), also the data of symptoms presence, like spots, sporulation over the spots and the data of tracing of each sporulation spot, during all the time that the leaflet was in the plant. For the NCAA, was proceeded to the contrary

\section{A model based} on the variation of general climate conditions is not dependable, because those conditions change every year. The model present here, is based on the biological response of the parasite, to the change of microclimate variables, which in turn affect the plant in simultaneous form. 
way that for the CCA case, the sporulation data were taken and then the ambient condition data were analyzed. The range of $\mathrm{RH}$ was always between 50 and $99 \%$, so the $\mathrm{Ph}$ in field condition and as it is presented in the table 1, the values of humidity and the $\mathrm{Ph}$ in the two cases (CCA and NCCA) coincide in a $100 \%$.

\section{The temperature}

The evaluated temperatures in CCA, were classify in: low 4 and $9^{\circ} \mathrm{C}$, medium 15 and $18^{\circ} \mathrm{C}$ and high 30, 33, 35 y $40^{\circ} \mathrm{C}$ (Zambrano and Filgueira 2013), in those ranges was possible to determinate the activity of $P$. sparsa sporulation moment, in leaflet of the Charlotte variety. Like the previous case, other climate variables remained constant, like is the case of the $\mathrm{RH}$ that remained above $90 \%$, where previous studies showed the maxims values of sporulation. We worked with a photoperiod of 12/12 and light intensity of 790 lx (Zambrano y Filgueira, 2013).

The infection of $P$. sparsa was evident to $4^{\circ} \mathrm{C}$, but the sporulation level was lowered and was few frequent in all the repetitions. The sporulation started to be evident to $9^{\circ} \mathrm{C}$ with values below $40 \%$ (Zambrano and Filgueira, 2013). The higher inoculum concentration and sporulation percentage was observed in the range of 15 and $18^{\circ} \mathrm{C}$ with percentage of $\mathrm{Ph}$ of 60 and $50 \%$ respectively. The sporulation was evident to $33^{\circ} \mathrm{C}$, showing the parasite adaptation to tropical ambient conditions. To $30^{\circ} \mathrm{C}$, the reduction of the sporulation was important and its values does not overcome the $18 \%$. To temperature above $35^{\circ} \mathrm{C}$, the infection was not present and changes in the leaflet were not evident (Zambrano and Filgueira, 2013). In accord with the results, it is possible to find abundant sporulation in temperatures between 9 and $33^{\circ} \mathrm{C}$, confirming that $P$. sparsa has the ability of reproduction in a wide range of temperatures

Like in the $\mathrm{RH}$ case, the observation window of the temperature was between $12 \mathrm{am}$ to $5 \mathrm{am}$, the night before. Therefore, if the temperature the night before was between the range of $15^{\circ} \mathrm{C}$ and $18^{\circ} \mathrm{C}$, to CCA the probability of sporulation (Pt) is $100 \%$. If the temperature was in the range of 10 and $14^{\circ} \mathrm{C}$, $\mathrm{Pt}$ has a value of $75 \%$. If the range of temperature the night before was between $4^{\circ} \mathrm{C}$ and $9^{\circ} \mathrm{C}$, Pt can reduced to $50 \%$, and if the range of temperature grew to between 22 and $33^{\circ} \mathrm{C}$, Pt falls to $25 \%$. Finally, above $34^{\circ} \mathrm{C}$, not was present sporulation, so $\mathrm{Pt}$ is $0 \%$ (see Table 1).

\section{Model of sporulation}

The epidemiologic prediction models applied to the case of rose downy mildew, in general are complex and its prediction capacity is determinate by the capacity to estimate a considerable number of variables, which in most of the cases are no easy to obtain (de Visser, 1998; Madden, et al., 2000; and Aegerter, et al., 2003). A model based on the variation of general climate conditions is not dependable, because those conditions change every year. The model present here, is based on the biological response of the parasite, to the change of microclimate variables, which in turn affect the plant in simultaneous form.

In the Table 1 is presented the probability sporulation values $(\mathrm{Pe})$, calculated for each case: Pe worth zero (null risk), when under any $\mathrm{RH}$ condition, the temperature is above of $34^{\circ} \mathrm{C}$ for the CCA case or by above of $17^{\circ} \mathrm{C}$ for the NCCA case. Equally, Pe takes a value of zero, when $\mathrm{RH}$ is below of $68 \%$, in any of the both cases CCA and NCCA. Pe takes a value of $6.25 \%$ (very low risk), when $\mathrm{RH}$ present the value between 69 and $78 \%$ and the temperature achieve values between $22^{\circ} \mathrm{C}$ and $33^{\circ} \mathrm{C}$ to CCA or 12 and $16^{\circ} \mathrm{C}$ to NCCA.

The next case of risk low is present when Pe takes a value of $12.5 \%$ that is possible in two events. First, when $\mathrm{RH}$ achieve values between 69 and $78 \%$ the 
night before, and the temperature was between 4 and $9^{\circ} \mathrm{C}$ in the case of CCA and between 0 and $3^{\circ} \mathrm{C}$ in the case of NCCA. Second, when RH was between 79 and $84 \%$, and the temperature between 22 and $33^{\circ} \mathrm{C}$, in the CCA case and between 12 and $16^{\circ} \mathrm{C}$ in the NCCA case. Pe takes a value of $18.75 \%$ (moderately low risk), in two conditions. First, when $\mathrm{RH}$ was between 69 and $78 \%$ and the temperature was between 10 and $14^{\circ} \mathrm{C}$ in the CCA case and between 8 and $11^{\circ} \mathrm{C}$ in the NCCA conditions. Second, when $\mathrm{RH}$ was between 85 and $90 \%$, and the temperature between 22 and $33^{\circ} \mathrm{C}$ in the CCA case or between 12 and $16^{\circ} \mathrm{C}$ in the NCCA case. Pe take the worth $25 \%$ (moderate medium risk), in the following cases:
1) when $\mathrm{RH}$ presented the values between 69 and $78 \%$ and the temperature, the values between 15 and $18^{\circ} \mathrm{C}$ in the CCA case and between 4 and $17^{\circ} \mathrm{C}$ for NCCA case. 2) When RH was between 79 and $84 \%$ and the temperature between 4 and $9^{\circ} \mathrm{C}$ in the NCCA case or between 0 and $3^{\circ} \mathrm{C}$ in the NCCA case. 3) for $\mathrm{RH}$ longer than or equal to $91 \%$ and the temperature between 22 and $33^{\circ} \mathrm{C}$ to CCA or between 12 and $16^{\circ} \mathrm{C}$ for NCCA.

The case of risk moderately high, it is present when $\mathrm{Pe}$ has the value of $37.5 \%$, that value is present in two occasions, the first when $\mathrm{RH}$ presented values between 79 and $84 \%$ and the temperature between 10 and $14^{\circ} \mathrm{C}$ in the case of CCA or between 8 and

Table 1. Probability of sporulation (Pe), of $P$. sparsa, in commercial roses under controlled conditions (CCA), (left side), and under field conditions or conditions not controlled (NCCA), (right side). To calculate Pe was used the sporulation probability (Ph) in the case of the relative humidity (RH) and the sporulation probability $(\mathrm{Ph})$ in the case of the temperature $(\mathrm{Pt})$.

\begin{tabular}{|c|c|c|c|c|c|c|}
\hline Pe of CCA & $\begin{aligned} P h & =0 \% \\
R H & \leq 68 \%\end{aligned}$ & $\begin{array}{c}\mathrm{Ph}=25 \% \\
69 \leq \mathrm{RH} \leq 78\end{array}$ & $\begin{array}{c}\mathrm{Ph}=50 \% \\
79 \leq \mathrm{RH} \leq \mathbf{8 4}\end{array}$ & $\begin{array}{c}\mathrm{Ph} 75 \% \\
85 \leq \mathrm{RH} \leq \mathbf{9 0}\end{array}$ & $\begin{array}{c}\mathrm{Ph}=100 \% \\
\mathrm{RH} \geq 91\end{array}$ & $\begin{array}{l}\text { Pe of } \\
\text { NCCA }\end{array}$ \\
\hline $\begin{array}{c}\mathrm{Pt}=0 \% \\
\mathrm{~T}^{\circ} \mathrm{C} \leq 34^{\circ} \mathrm{C}\end{array}$ & $\mathrm{Pe}=0 \%$ & $P e=0 \%$ & $\mathrm{Pe}=0 \%$ & $\mathrm{Pe}=0 \%$ & $\mathrm{Pe}=0 \%$ & $\begin{aligned} \mathrm{Pt} & =0 \% \\
\mathrm{~T}^{\circ} \mathrm{C} & \leq 17^{\circ} \mathrm{C}\end{aligned}$ \\
\hline $\begin{array}{c}\mathrm{Pt}=25 \% \\
22^{\circ} \mathrm{C} \leq \mathrm{T}^{\circ} \mathrm{C} \\
\leq 33^{\circ} \mathrm{C}\end{array}$ & $\mathrm{Pe}=0 \%$ & $\begin{array}{c}\text { Case } 1 \\
P e=6,25 \%\end{array}$ & $\begin{array}{c}\text { Case } 2 \\
\mathrm{Pe}=12,5 \%\end{array}$ & $\begin{array}{c}\text { Case } 3 \\
\mathrm{Pe}=18.75 \%\end{array}$ & $\begin{array}{c}\text { Case } 4 \\
P e=25 \%\end{array}$ & $\begin{array}{c}\mathrm{Pt}=25 \% \\
12^{\circ} \mathrm{C} \leq \mathrm{T}^{\circ} \mathrm{C} \\
\leq 16^{\circ} \mathrm{C}\end{array}$ \\
\hline $\begin{array}{c}\mathrm{Pt}=50 \% \\
4^{\circ} \mathrm{C} \leq \mathrm{T}^{\circ} \mathrm{C} \\
\leq 9^{\circ} \mathrm{C}\end{array}$ & $\mathrm{Pe}=0 \%$ & $\begin{array}{c}\text { Case } 5 \\
P e=12,5 \%\end{array}$ & $\begin{array}{c}\text { Case } 6 \\
P e=25 \%\end{array}$ & $\begin{array}{c}\text { Case } 7 \\
\mathrm{Pe}=37.5 \%\end{array}$ & $\begin{array}{c}\text { Case } 8 \\
P e=50 \%\end{array}$ & $\begin{array}{c}\mathrm{Pt}=50 \% \\
0^{\circ} \mathrm{C} \leq \mathrm{T}^{\circ} \mathrm{C} \\
\leq 3^{\circ} \mathrm{C}\end{array}$ \\
\hline $\begin{array}{c}\mathrm{Pt}=75 \% \\
10^{\circ} \mathrm{C} \leq \mathrm{T}^{\circ} \mathrm{C} \\
\leq 14^{\circ} \mathrm{C}\end{array}$ & $\mathrm{Pe}=0 \%$ & $\begin{array}{c}\text { Case } 9 \\
P e=18.75 \%\end{array}$ & $\begin{array}{c}\text { Case } 10 \\
\mathrm{Pe}=37.5 \%\end{array}$ & $\begin{array}{c}\text { Case } 11 \\
\mathrm{Pe}=56.25 \%\end{array}$ & $\begin{array}{c}\text { Case } 12 \\
\mathrm{Pe}=75 \%\end{array}$ & $\begin{array}{c}\mathrm{Pt}=75 \% \\
8^{\circ} \mathrm{C} \leq \mathrm{T}^{\circ} \mathrm{C} \\
\leq 11^{\circ} \mathrm{C}\end{array}$ \\
\hline $\begin{array}{c}\mathrm{Pt}=100 \% \\
15^{\circ} \mathrm{C} \leq \mathrm{T}^{\circ} \mathrm{C} \\
\leq 18^{\circ} \mathrm{C}\end{array}$ & $\mathrm{Pe}=0 \%$ & $\begin{array}{c}\text { Case } 13 \\
\mathrm{Pe}=25 \%\end{array}$ & $\begin{array}{c}\text { Case } 14 \\
\mathrm{Pe}=50 \%\end{array}$ & $\begin{array}{c}\text { Case } 15 \\
\mathrm{Pe}=75 \%\end{array}$ & $\begin{array}{c}\text { Case } 16 \\
P e=100 \%\end{array}$ & $\begin{aligned} & \mathrm{Pt}=100 \% \\
& 4^{\circ} \mathrm{C} \leq \mathrm{T}^{\circ} \mathrm{C} \\
& \leq 7^{\circ} \mathrm{C}\end{aligned}$ \\
\hline
\end{tabular}




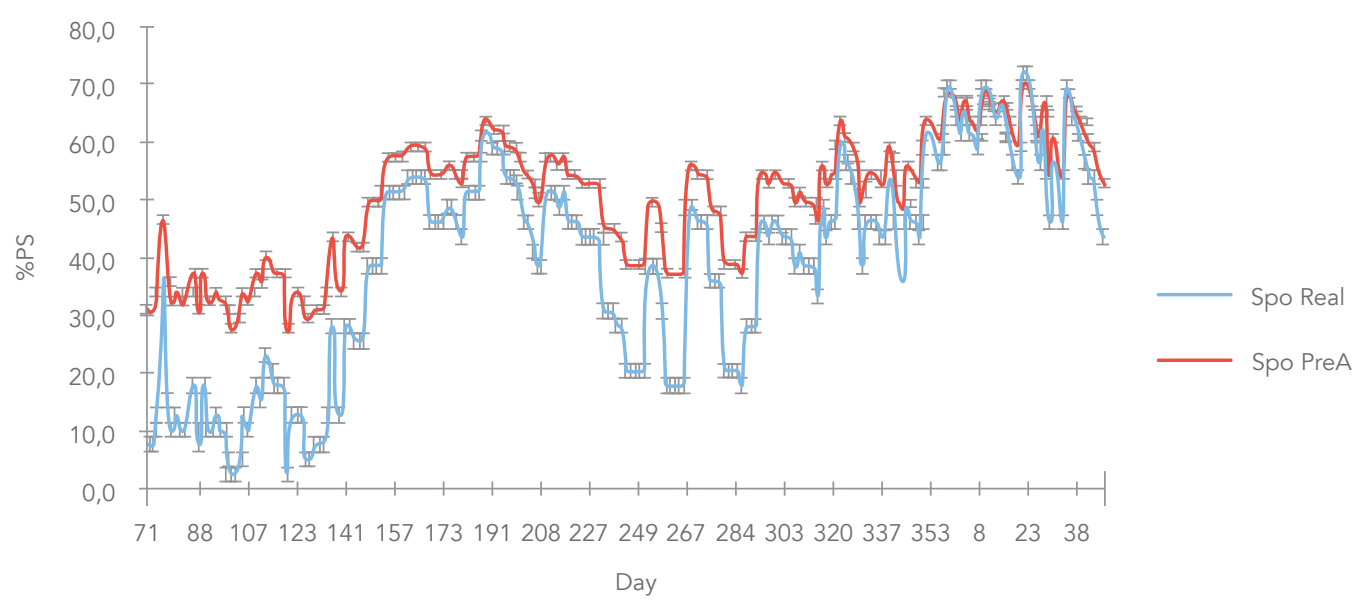

Figure 1. Results of compare the real sporulation values of 343 samples (blue lines), with the prediction of sporulation using the model (red lines). Appear the variance values in each case, which not overcome the $5 \%$ in no case. The adjustment value of the model is superior to $95 \%$. (\% Ps is the Probability of sporulation, Day is Julian day of the year, Spo Real is the sporulation real and Spo PreA is the adjusted predicted sporulation).

$11^{\circ} \mathrm{C}$ in the case of NCAA. The second situation is present when HR was between 85 and $90 \%$ and the temperature between 4 and $9{ }^{\circ} \mathrm{C}$ for the CCA case or between 0 and $3^{\circ} \mathrm{C}$ in the NCAA case. The risk is high in two cases of $\mathrm{Pe}$. First, when $\mathrm{Pe}$ is $50 \%$ and that value is presented in two cases of the $\mathrm{RH}$; the firsts, when the RH was between 79 and $84 \%$ and the temperature between 15 and $18^{\circ} \mathrm{C}$ in the CCA case and between 4 and $7^{\circ} \mathrm{C}$ in the NCCA case. The second case is when the $\mathrm{RH}$ is longer than $92 \%$, with temperature between 4 and $9^{\circ} \mathrm{C}$ for CCA and between 0 and $3^{\circ} \mathrm{C}$ for NCCA. The other case of high risk is when $\mathrm{Pe}$ value is $56 \%$ and it is present when the $\mathrm{RH}$ was between 85 and $90 \%$ and the temperature between 10 and $14^{\circ} \mathrm{C}$ case of CCA and between 8 and $11^{\circ} \mathrm{C}$ in the case of NCCA. Pe present the more high risk when take the values of 75 and $100 \%$, the first case is present in two different situations, first when the $\mathrm{RH}$ was between 85 and $90 \%$ and the temperature between 15 and $18^{\circ} \mathrm{C}$ for the vase of CCA and between 4 and $7{ }^{\circ} \mathrm{C}$ for the case NCCA. The second situation was when the $\mathrm{RH}$ is above $91 \%$ and the temperature between 10 and $14^{\circ} \mathrm{C}$ for the CCA case and between 8 and $11^{\circ} \mathrm{C}$ for the NCCA case. Finally, Pe take the value of $100 \%$ when the $\mathrm{RH}$ achieve the value mayor or equal of $91 \%$ and the temperature 15 and $18^{\circ} \mathrm{C}$ for the case of CCA and between 4 and $7^{\circ} \mathrm{C}$ for the NCCA case.

\section{Model validation}

To validate the model we take the 343 registers of temperatures and $\mathrm{RH}$, in which were present different sporulation values, measured by the sporulation percentage and under different conditions. We determinate in what case of the table 1, each register pertain (see Table 1.). Using the designed software (is not showed here), was calculated the value of the prediction of the sporulation based in the model, comparing with the values of the real sporulation.

The model prediction data is adjusted to the real data with a value superior to $95 \%$, like is possible to observe in the Figure 1. The model is adjusted in a best form to the probabilities highs and mediums, 


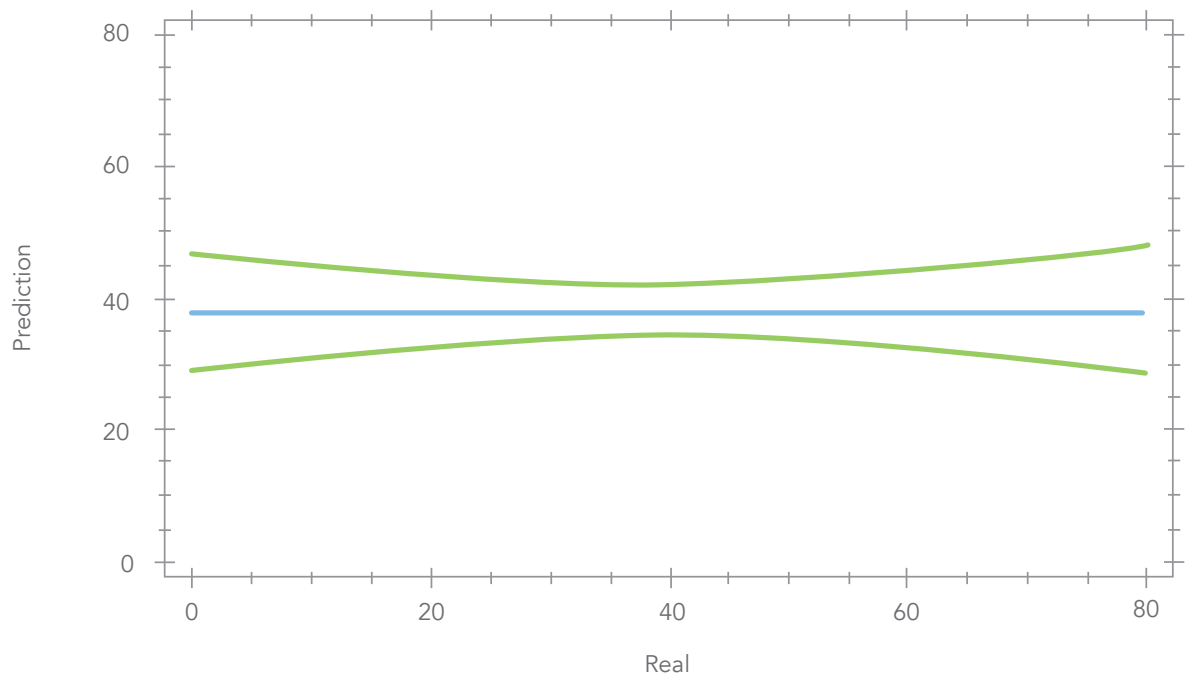

Figure 2. The graphic of the model adjusted in relation to the real data, using simple linear regression, the green lines are the limit of the prediction and the blue line is the adjusted prediction.

more than to the lows probabilities. That produced that the model be more useful for the flower growers, because the risk low is easier to control using microclimate conditions, than the values of high risk or medium, that are the responsible by maintain the level of inoculum in the crop.

For validating the model, we used the simple regression for the comparison between the model versus the real data, where the dependent variable is the prediction and the independent variable is the real data (Figure 2), the adjusted equation of the model is:

$$
\begin{gathered}
\text { Adjusted sporulation predicted }= \\
26.3+(0.6 \text { * real sporulation })
\end{gathered}
$$

For the correlation analysis, we calculated the Pearson coefficient where was taken into account the sample size. Being the P-value in the coefficient less than 0.05 , showing than exist one relation significant statistically between the regressions of the real data and the prediction, with a confidence level higher than of $95 \%$. The correlation coefficient between the real model and the adjusted one is equal to 0.29 . The range of those correlation coefficients goes of -1 to +1 , and measure the strength of the linear relation between the variables.

\section{CONCLUSION}

The rose downy mildew is one of the problems in the rose crop that produced the most expenses to the floriculture in Colombia and Ecuador. There are not methods of control different from the fungicides used and the missed are large in special in the production picks. The prediction models developed until now by other authors for the rose downy mildew has not showed be useful in the disease control, because its complexity to be used by the growers. Here we present a $P$. sparsa sporulation prediction model with more than $95 \%$ of success probability, based on two culture conditions, 1) greenhouses with climatic 
conditions controlled and that the temperature in the early morning not higher than 20 Celsius, and 2) greenhouses with climate condition not controlled, with temperatures in early morning near 5 Celsius. To apply the model only we need to estimate two microclimatic variables, the temperature and the relative humidity the night before to the prediction between the 12am and $5 \mathrm{am}$. The measures must be perform into the greenhouse and very near of the plant, that is referred like microclimate conditions, with equipment analog or digital but of continuous register. The application of the prediction model allows take decisions about fungicide application and it will permit in the time reduce the production cost.

\section{ACKNOWLEDGMENT}

Authors thank the Military University "Nueva Granada" and COLCIENCIAS by contribute with the funds to develop the different works allowing the development of the model.

\section{REFERENCES}

1. Aegerter, B.J., Nuñez, J.J. and Davis, R.M. 2003. Environmental factors affecting rose downy mildew and development of a forecasting model for a nursery production system. Plant Disease. 87, 732-738.

2. Arbeláez, G. 1999. El mildeo velloso del rosal ocasionado por Peronospora sparsa Berkeley. Acopaflor 6, 37 - 39.

3. Ayala, M., Angel, L.E., Jaramillo, S., Montoya, M. 2008. Diversidad genética de Peronospora sparsa (peronosporaceae) en cultivos de rosa de Colombia. Acta Biológica Colombiana. 13 (1), 79 - 94.

4. Bombelli, E.C., Wright, E.R., Moschini, R.C., López, M.V., Fabrizio, M.C., Barberis, J.G., Rivera, M.C. 2012. Modelado computacional de datos epidemiológicos para predecir enfermedades de cultivos con base meteorológica. Instituto de $\mathrm{Cli}$ ma y Agua. INTA Castelar. Buenos Aires. Argentina

5. Castillo C. F., E. Álvarez, E. Gómez, G. A. Llano and Castaño,J. 2010. Mejoramiento nutricional de la rosa para el manejo de Peronospora sparsa Berkeley, causante del mildeo velloso. Rev. Academia Colomblana de Ciencias 34 (131), 137-142.

6. De Visser, C.L.M. 1998. Development a downy mildew advisor model based on downcast. Europeal Jornal of Plant Pathology, 104, 933-943.

7. De Vis, R. 1999. Manejo del mildeo velloso en rosa con control climático. Acopaflor 6 (6), 14-19.

8. Gómez, S. 2004. Determinación de componentes de la biología de Peronospora 
sparsa Berkeley, y caracterización de la respuesta de tres variedades de rosa a la infección del patógeno bajo condiciones de laboratorio e invernadero. Tesis de maestría. Facultad de Agronomía, Universidad Nacional de Colombia, Bogotá.

9. Gómez, S. y Arbeláez, G. 2005. Efecto de la temperatura en el periodo de latencia y producción de esporangios de Peronospora sparsa Berkeley en tres variedades de rosa. Agronomía Colombiana 23 (2), 239-245.

10. Gomez, S.Y. and Filgueira, J.J. 2012. Monitoring the infective process of the downy mildew causal agent within micro propagated rose plants. Agronomía Colombiana 30 (2), 214-221.

11. Hildebrand, P.D. and Sutton, J.C. 1984. Interactive effects of the dark period, humid period, temperature, light on sporulation of Peronospora destructor. Phytopathology. 74 (12), 1444-1449.

12. Hildebrand, P.D. and Sutton, J.C. 1985. Environmental water in relation to Peronospora destructor and related pathogens. Canadian Journal of Plant Pathology 7, 323 - 330.
13. Hoppmann, D. and Wittich, KP. 1997. Epidemiology-related modelling of the leafwetness duration as an alternative to measurements, taking Plasmopara viticola as an example. Zeit. Pflanzenkrank. Pflanzenschutz (Journal Plant Disease Protection) 104, 533-544.

14. Horst, R. 1983. A compendium of rose disease. APS Press, St. Paul, USA.

15. Madeen, L.V., Ellis, M.A., Lalancette, N., Hughes, G. and Willson, L.L. 2000. Evaluation of a disease warming system for downy mildew of grapes. Plant Disease, 84, 549-554.

16. Margulis, L. 1998. Symbiotic Planet. A New Look at Evolution. Brockman, Massachusetts, EEUU. Ist Edt.

17. Monroy, I.E. y Filgueira, J.J. 2009. La humedad relativa en la infección y esporulación del moldeo velloso de la rosa Peronospora sparsa Berkeley como método para controlar la enfermedad. Asocolflores. 73. septiembreDiciembre, 45-50.

18. Prescott, L., Harley, J. and Klein, D. 1999. Microbiology. $4^{\text {th }}$ Ed. Editorial Mc Graw-Hill, 125-127. 
19. Soo, K.K., Beresford, M.R.M. and Walter, M. 2014. Development of a disease risk prediction model for Downy mildew (Peronospora sparsa) in Boysenberry. Phytopathology 104 (1), 50-56.

20. Soto, J. Y Filgueira, J. 2009. Efecto del fotoperiodo y la intensidad lumínica sobre la esporulación de Peronospora sparsa Berkeley bajo condiciones controladas. Agronomía Colombiana. 27 (2), 245-251.

21. Zambrano, G. and Filgueira, J.J. 2013. Efecto de la temperatura en el desarrollo del mildeo velloso de la rosa (Peronospora sparsa) en un sistema de condiciones ambientales controladas. Fitopatología Colombiana, 37 (1). 57.

22. Virnnot-Bourgin, G. 1981. History and importance of downy mildews. In Spencer, D.M. Ed. The downy mildews. Academic Press, London. 1-13

23. Wheeler, B.E.J. 1981. Downy Mildew of ornamentals, In: Spencer DM. Ed. The Downy Mildews.Academic Press, London, 473-485. 